NASZA DERMATOLOGIA Onlin OUR DERMATOLOGY Online

Source of Support: Nil

Competing Interests: None

\section{Hairy ears; Revisited}

Daifullah Al Aboud

Dermatology Department, Taif University, Taif, Saudi Arabia

Corresponding author: Dr. Daifullah Al Aboud dalaboud@hotmail.com
Hair can grow in areas which are not usually hairy in human skin. The Online Mendelian Inheritance in Man (OMIM) (http:// www.ncbi.nlm.nih.gov/omimhave) some entries in this regards. These include (\%139600 - HAIRY ELBOWS, \#605130 - HAIRY ELBOWS, SHORT STATURE, FACIAL DYSMORPHISM, AND DEVELOPMENTAL DELAY, 139630 - HAIRY NOSE TIP, 139500 - HAIRY EARS, and 425500 - HAIRY EARS, Y-LINKED).

Hairy ears, (Fig. 1), are uncommon trait and it is rare to see a person with very long hair on the ears. There is already Guinness World Record for the longest hair on the ears.

This trait is commonly seen in people from some parts of India [1-6] and Sri Lanka [7]. However, it has been observed in other ethnic groups. There are reports of its occurrence in persons from Malta [8], Australia [9], Egypt [10], Malaysia [11], Nigeria [12], and Japan [13].

The increased hair on the ears can involve meatal opening,

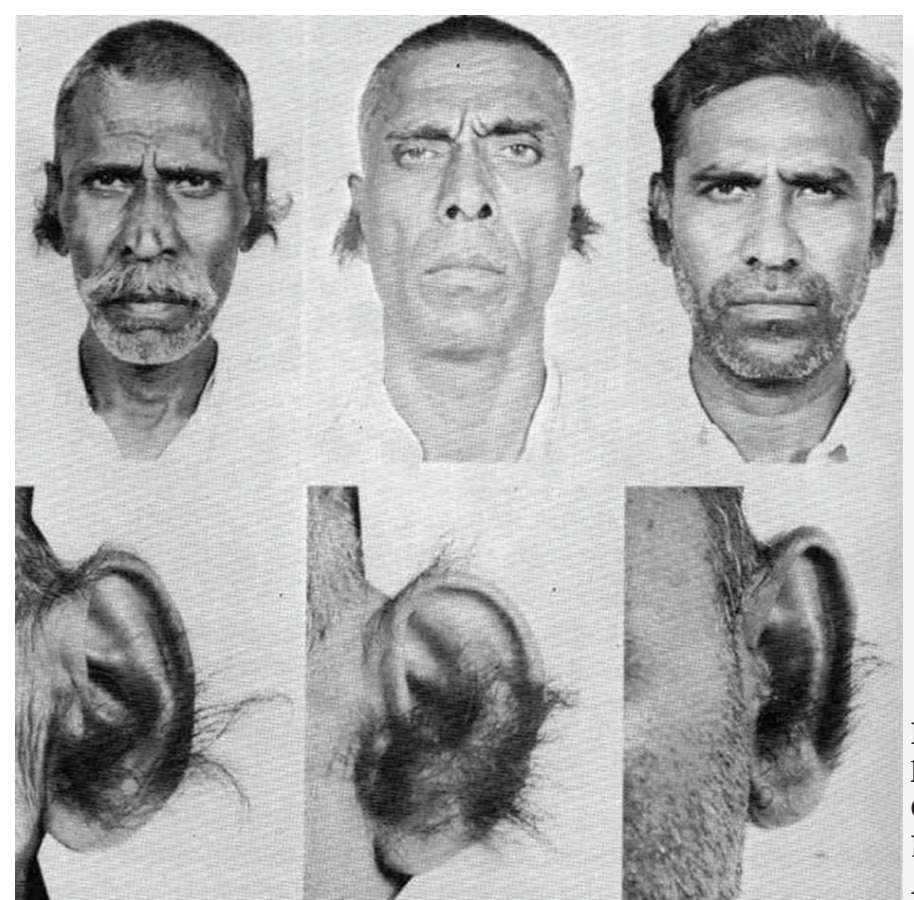

Figure 1. Hairy ears.Available online at; http://www.mun.ca/biology/scarr/Hairy_Ears.html.

Courtesy of Dr Steven M Carr, Professor of Biology, Dept. of Biology, Memorial University of Newfoundland, St John's NL A1B 3X9, Canada. pinnae (Hypertrichosis pinnae auris) or the external rim. The type of hair can be lanugo or terminal type of hair.

It was originally described as a $\mathrm{Y}$ chromosome-linked trait 1 $[5,15]$. However, it is believed now that it is not linked to it.

Hairy ears is mainly of a cosmetic concern. However, hairy ears have been described in infants born of diabetic mothers [16,17], a baby with congenital malformation [18], in association with human immunodeficiency virus (HIV) infection [19], in patient with cancer (lanugo hair) [20] and after using some medications [21-23]. There is also report of infection of the ear being precipitated by increased hair on the ears [23].

Increased hair on the ears can be also a feature of conditions and syndromes with generalized hypertrichosis [24,25].

In (Fig. 2), I proposed a clinical scheme to approach a person with hairy ears.

Long hair on the ears can be cut by trimming and can also be removed by shaving, waxing and laser. 


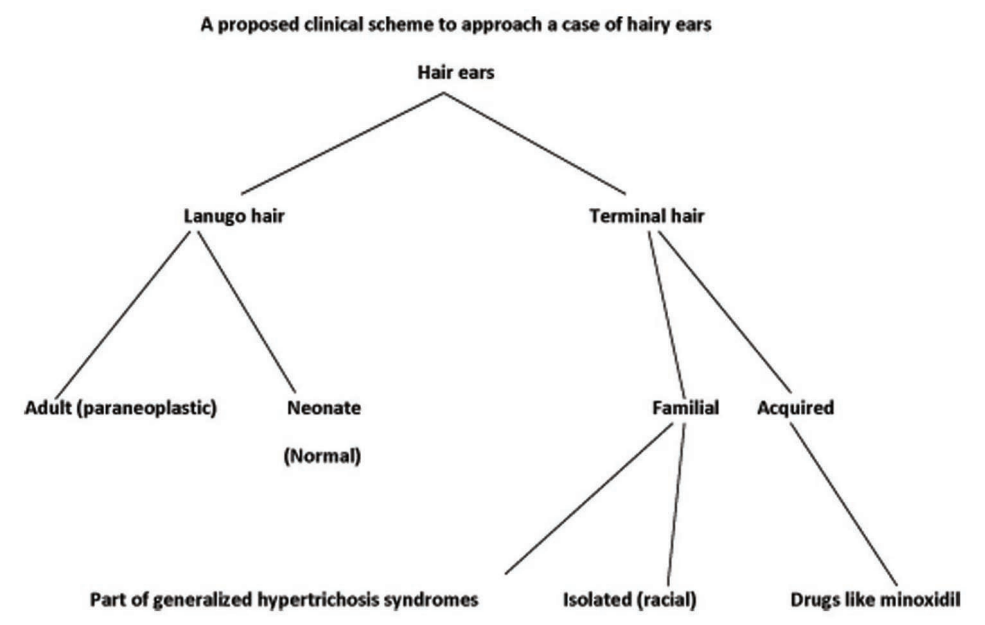

Figure 1. A proposed clinical scheme to approach a person with hairy ears.

\section{REFERENCES}

1. Bharadwaj VK, Anand CS, Chaurasia BD. Hair patterns of the pinna among the Central Indians. Anthropol Anz. 1977;36:20-6.

2. Chakravartti MR. Hairy pinnae in Indian populations. Acta Genet Stat Med. 1968;18:511-20.

3. Ali SG. Hairy pinnae in Kerala. Am J Phys Anthropol. 1972;36:1535.

4. Gates RR. Records of Y-inherited hairy ears in India. Acta Genet Med Gemellol (Roma). 1957;6:103-8.

5. Veerraju P, Satyanarayana M. Hypertrichosis pinnae auris in Coastal Andhra population. Jinrui Idengaku Zasshi. 1973;18:37-41.

6. Singh L, Goel KV, Mahendru P. Hypertrichosis pinnae auris, Darwin's tubercle and Palmaris Longus among Khatris and Baniyas of Patiala, India. Acta Genet Med Gemellol (Roma). 1977;26:183-4.

7. Dronamraju KR. Frequencies of hairy pinnae among Indian and Sinhalese peoples. Nature. 1961;190:653.

8. Ruggles Gates R, Vella F. Hairy pinnae in Malta. Lancet. 1962;(ii):357.

9. Abbie AA, Rao PD. Hairy pinna in Australian Aborigines. Hum Biol. 1965;37:162-73.

10. El Wakil HE, El Gewely MR, Dronamraju KR. The age of onset of hypertrichosis pinnae auris among Egyptians. Hum Biol. 1967;39:414-7.

11. Pallie W. „Hypertrichosis pinnae auris” in Malaysian peoples. Med J Malaya. 1968;23:67-72.

12. Stern C, Schaefer A, Ukpe OJ. Hairy pinnae in Nigeria. J Hered. 1968;59:174 passim.

13. Stern C, Tokunaga C. Hairy ear rims in Japanese. J Hered. 1965; 56:218-9.

14. Dronamrajn KR. Hypertrichosis of the pinnae of the human ear, Y-linked pedigrees. J Genet. 1961;51:230-43.
15.Kamalan A, Thambiah AS. Genetics of hairy ears in South Indians. Clin Exp Dermatol. 1990;15:192-4.

16. Rafaat M. Hypertrichosis pinnae in babies of diabetic mothers. Pediatrics. 1981;68:745-6.

17. Singh M, Kumar A, Paul VK. Hairy pinna--a pathognomonic sign in infants of diabetic mothers. Indian Pediatr. 1987;24:87-9.

18. Chaurasia BD, Goswami HK. Congenitally malformed female infant with hairy pinnae. Clin Genet. 1971;2:111-4.

19. Tosti A, Gaddoni G, Peluso AM, Misciali C, Piraccini BM, Menni B. Acquired hairy pinnae in a patient infected with the human immunodeficiency virus. J Am Acad Dermatol. 1993;28:513.

20. Knowling MA, Meakin JW, Hradsky NS, Pringle JF. Hypertrichosis lanuginosa acquisita associated with adenocarcinoma of the lung. Can Med Assoc J. 1982;126:1308-10.

21. Sänger CF, Dietrich N, Pelivani N, Borradori L, de Viragh PA. Hairy pinnae after orchiectomy and chemotherapy for testicular cancer: acquired localized hypertrichosis of the ears. Dermatology. 2011;222:289-91.

22. Toriumi DM, Konior RJ, Berktold RE. Severe hypertrichosis of the external ear canal during minoxidil therapy. Arch Otolaryngol Head Neck Surg. 1988;114:918-9.

23. Lancaster J, Alderson DJ, McCormick M. Non-pseudomonal malignant otitis externa and jugular foramen syndrome secondary to cyclosporin-induced hypertrichosis in a diabetic renal transplant patient. J Laryngol Otol. 2000;114:366-9.

24.Baumeister FA, Egger J, Schildhauer MT, Stengel-Rutkowski S. Ambras syndrome: delineation of a unique hypertrichosis universalis congenita and association with a balanced pericentric inversion (8) (p11.2; q22). Clin Genet. 1993;44:121-8.

25.Torbus O, Sliwa F. [Ambras syndrome--a form of generalised congenital hypertrichosis]. Pol Merkur Lekarski. 2002;12:238-40.

Copyright by Daifullah Al Aboud. This is an open access article distributed under the terms of the Creative Commons Attribution License, which permits unrestricted use, distribution, and reproduction in any medium, provided the original author and source are credited. 